\title{
Pemanfaatan Asap Cair Hasil Pirolisis Batubara sebagai Pestisida Organik pada Rayap (Coptotermes curvignathus Holmgren)
}

\author{
Utilization of Liquid Smoke Results of Coal Pyrolysis as Pesticides on Wings \\ (Coptotermes curvignathus Holmgren)
}

\author{
Muh Arman ${ }^{1 *}$, Suriyanto Bakri², Rafdi Abdul Majid ${ }^{1}$ \\ ${ }^{1}$ Departemen Teknik Kimia, Fakultas Teknologi Industri, Universitas Muslim Indonesia \\ ${ }^{2}$ Departemen Teknik Pertambangan, Fakultas Teknologi Industri, Universitas Muslim Indonesia \\ Jl. Urip Sumoharjo km.5 Makassar, 90231, Indonesia \\ *Email: m.arman@umi.ac.id
}

\begin{abstract}
Abstrak
Pirolisis merupakan suatu proses dekomposisi kimia material melalui metode pemanasan tanpa adanya oksigen atau sedikit oksigen. Pemanfaatan batubara sebagai bahan baku pembuatan asap cair diharapkan mampu menghasilkan pestisida yang memiliki nilai ekonomis dan dapat digunakan sebagai pembasmi rayap. Tujuan peneltian ini dilakukan untuk menentukan konsentrasi dan waktu optimum asap cair batubara sebagai pestisida terhadap mortalitas serangga rayap (Coptotermes curvignathus Holmgren). Metode yang dilakukan yaitu proses pirolisis batubara pada suhu $300{ }^{\circ} \mathrm{C}$. Proses pengujian mortalitas pada rayap dengan variabel waktu dankonsentrasi. Penentuan kandungan asap cair batubara dilakukan analisa kualitatif dan kuantitatif. Dari hasil penelitian diperoleh waktu optimum dari mortalitas rayap yaitu 25 menit dengan konsentrasi optimum $80 \%$ dimana diperoleh mortalitas rayap sebesar $100 \%$. Berdasarkan hasil Analisa Spektrofotometer UV/VIS diperoleh kadar sulfur dari asap cair batubara sebesar 46,92 mg/kg dan derajat keasaman (pH) 3,00. Kandungan keasaman yang cukup tinggi sehingga memungkinkan pestisida dari asap cair batubara bisa dimanfaatkan secara luas dalam bidang pertanian.
\end{abstract}

Kata kunci: asap cair, pestisida, pirolisis batubara

\begin{abstract}
Pyrolysis is a process of chemical decomposition of materials through a heating method in the absence of oxygen or a little oxygen. The utilizing coal as a raw material for making liquid smoke, it is hoped that it will be able to produce pesticides that have economic value and can be used as a termite exterminator. The use of coal as a raw material for making liquid smoke is expected to produce pesticides that have economic value and can be used as a termite repellent. This research aimed to determine the optimum concentration and time of liquid coal smoke as a pesticide against termite insect mortality (Coptotermes curvignathus Holmgren). The method used is the coal pyrolysis process at a temperature of $300{ }^{\circ} \mathrm{C}$. The process of testing the mortality of termites with time and concentration variables. The determination of the liquid smoke content of coal is carried out by qualitative and quantitative analysis. The results showed that the optimum time for termite mortality was 25 minutes with an optimum concentration of $80 \%$, where the termite mortality was obtained by $100 \%$. Based on the results of UV/VIS Spectrophotometer Analysis, the sulfur content of liquid coal smoke was 46.92 $\mathrm{mg} / \mathrm{kg}$, and the degree of acidity $(\mathrm{pH})$ was 3.00 . The acidity content is high enough to allow pesticides from liquid coal smoke to be widely used in agriculture.
\end{abstract}

Keywords: liquid smoke, pesticides, pyrolysis coal

\section{Pendahuluan}

Pirolisis merupakan proses dekomposi termokimia dari biomassa menjadi berbagai produk berupa padatan, cairan dan gas. Proses pirolisis berlangsung pada suhu tinggi tanpa adanya oksidator atau sedikit oksigen bahkan tanpa oksigen sama sekali.
Proses pirolisis memiliki kemiripan desain dengan proses destilasi.

Pirolisis dilakukan dengan memanaskan umpan yang ada dalam reaktor dengan menggunakan kecepatan panas tertentu. Suhu yang digunakan akan menentukan karakteristik padatan dan cairan yang 
dihasilkan. Cairan sebagai produk pemanasan ini diperoleh dengan mengkondensasikan uap hasil pirolisis pada sebuah wadah penampungan.

Cairan hasil pirolisis dikenal sebagai bio-oil, tar, bio-crude, asap cair, wood oil atau destilat kayu. Karakteristik dari asap cair ini berupa cairan berwarna coklat kehitaman. Cairan ini dapat dipisahkan akan membentuk tiga bagian utama. Fase minyak pada bagian atas cairan, fase aquaeos pada bagian tengah dan fase berat berupa tar pada bagian bawah. Fase aquaeos adalah fase yang mengandung asam organik, aldehida, keton, fenol, gula anhidrid, lignin dan air.

Proses pirolisis merupakan teknologi yang dapat dimanfaatkan untuk memproses batubara, Sulawesi Selatan memiliki potensi kandungan batubara yang cukup banyak namun tidak dapat dimanfaatkan sebagai bahan baku pada industri karena kandungan sulfur yang cukup tinggi. Berdasarkan hasil penelitian dari diperoleh jika proses pirolisis batubara dapat meningkatkan nilai kalori dan menurunkan kadar sulfur. Senyawa sulfur pada proses pirolisis akan terkondensasikan menjadi asap cair [1] .

Hasil penelitian dengan metode analisis kromatografi gas-spektrometri massa (GCMS) menunjukkan kandungan asap cair hasil pirolisis tempurung kelapa diketahui terdapat tujuh senyawa berupa metil ester asam oksalat $31,41 \%$, asam asetat 48,75\%, 1-hidroksi-2-propanon 7,25\%, 2,3butanadion $0,29 \%$, asam propanoat $4,01 \%$, fenol 3,19\%, dan 2-furan karboksaldehid 5,09\% [2].

Penelitian lain tentang aplikasi asap cair pada lateks. Setelah asap diaplikasikan kepada lateks dan diamati lembaran karet yang terbentuk, diperoleh ketebalan sit mutu 1 yaitu ketebalan $3 \mathrm{~mm}$. Lembaran Sit yang diberi asap cair $1 \%$ maupun $2 \%$, tidak berbau busuk namun berbau seperti asap, dan tidak tampak tumbuh jamur pada lembaran Sit. Hal ini akibat terjadinya dekomposisi dari senyawa-senyawa kimia membentuk senyawa fenol dan senyawa asam organik yang tinggi dengan nilai $\mathrm{pH}$ yang rendah mengakibatkan terhambatnya pertumbuhan pada sit mikroba karena senyawa-senyawa ini bekerja sebagai zat antioksidan. Akibatnya pertumbuhan jamur dan bau busuk pada sit yang sudah dibiarkan selama seminggu tidak terjadi [3]. Penggunaan batubara ( $s u b$ bituminus) sebagai bahan baku pembuatan asap cair pada penelitian ini disebabkan dengan tingginya kandungan sulfur. Sebuah penelitian menunjukkan jika pestisida alami kalsium polisulfida pada dosis uji yang paling rendah $1,25 \mathrm{~mL} / \mathrm{L}$ air sudah mampu menyebabkan mortalitas tungau lebih dari 50\% [4].

Sebuah penelitian juga menunjukkan bahwa biomassa yang bersumber dari cangkang sawit dan tempurung kelapa yang diolah menjadi asap cair memiliki efektifitas sebagai insektisida organik yang sangat baik di mana asap cair ini dapat mematikan serangga/hama dengan waktu yang singkat [5].

Penelitian tentang pemanfaatan asap cair hasil pirolisis dari bahan batubara menjadi pestisida organik pada rayap (Coptotermes curvignathus Holmgren) dapat dilakukan berdasarkan hasil studi literatur dan survei lokasi sumber bahan baku utama yang cukup melimpah dan belum termanfaatkan.

Berdasarkan uraian teoritis, maka rumusan masalah yang dapat dijadikan sebagai bahan penelitian yaitu berapa konsentrasi dan waktu yang paling efektif dari asap cair hasil pirolisis batubara grade 3 sebagai pestisida pada rayap (Coptotermes curvignathus Holmgren). Diharapkan dengan penelitian ini menjawab tentang konsentrasi dan waktu yang paling efektif dari pestisida yang dihasilkan

\section{Teori}

Sumber cadangan batubara Provinsi Sulawesi Selatan berdasarkan pusat sumber daya geologi 2015 sebesar 231,58 ton. Sebaran kualitas batubara kalori rendah di Indonesia sebanyak 30,22\%, kalori sedang $64,88 \%$, kalori tinggi 4,85\%, dan kalori sangat tinggi $2,95 \%[6]$.

Biomassa berpotensi menjadi sumber hidrokarbon terbarukan, yang dapat menggantikan bahan bakar fosil dunia dalam berbagai aplikasi. Saat ini, beberapa jalur biologi dan kimia memanfaatkan biomassa sebagai sumber bahan kimia dan bahan bakar. Namun, jalur termokimia dapat menggunakan lebih banyak variasi bahan baku, memungkinkan mereka untuk memanfaatkan bahan lignoselulosa berbasis bukan makanan. Secara khusus, pirolisis disebut sebagai proses yang efektif untuk mengubah biomassa padat menjadi produk cair dengan hasil tinggi. Akan tetapi, komposisi bio-oil sedemikian rupa sehingga saat ini tidak dapat digunakan pada infrastruktur bahan bakar fosil yang ada untuk aplikasi yang menuntut, seperti bahan bakar transportasi [7].

Asap cair dapat dimanfaatkan sebagai pestisida sebagaimana dimanfaatkan sebagai bahan pengawet pada makanan yaitu asap cair yang telah diolah. Salah satu hasil penelitian bahwa asap cair digunakan sebagai pengawet ikan [8], asap cair mampu diterapkan sebagai metode pengasapan ikan [9].

Semua bahan yang dapat mempengaruhi kehidupan organisme maupun mikroorganisme biasa disebut sebagai pestisida atau semua bahan racun yang digunakan untuk membunuh jasad hidup yang mengganggu tumbuhan, ternak dan sebagainya yang diusahakan manusia untuk kesejahteraan hidupnya. Pada dasarnya pestisida yang beredar telah dalam bentuk formulasi yaitu campuran antara bahan aktif dengan bahan tambahan. Penambahan bahan tersebut berguna untuk memudahkan aplikasi, menambah efektifitas, menambah efisiensi dan keamanan dalam aplikasi.

Rayap merupakan salah satu jenis hewan perusak yang mempunyai peranan yang sangat besar dalam menyebabkan kerusakan pada bangunan, dengan populasi yang cukup besar dapat menyebabkan kerusakan yang signifikan [10]. Faktor iklim dan ketersediaan air memainkan peran penting dalam kelangsungan hidup rayap. Perubahan harian 
dan musim pada faktor-faktor ini juga mempengaruhi distribusi rayap [11].

Penggunaan pestisida pada rayap dari bahan asap cair akan sangat bermanfaat bagi masyarakat yang ada dipedesaan. Hal ini disebabkan banyaknya potensi sumber biomassa dan proses pembuatan yang bisa dilakukan secara sederhana. Penggunaan pestisida ini diharapkan mampu memberikan alternatif yang ramah lingkungan.

Salah satu produk Asap cair yang diperoleh dari bahan sabut kelapa berpotensi sebagai repelan terhadap hama padi walang sangit (leptocorisa oratorius). Hasil identifikasi asap cair ini memiliki kandungan utama berupa asam palmitat, metal oleat dan siklo tetraheksana yang mampu bekerja aktif sebagai repelan terhadap walang sangit hingga dapat menekan populasi karena bersifat anti mikroba dan bakteri bagi hama dan penyakit tanaman [12].

\section{Metodologi Penelitian}

\section{A. Alat dan Bahan}

1. Alat

Berikut ini adalah rangkaian alat pirolisis yang digunakan untuk produksi asap cair.

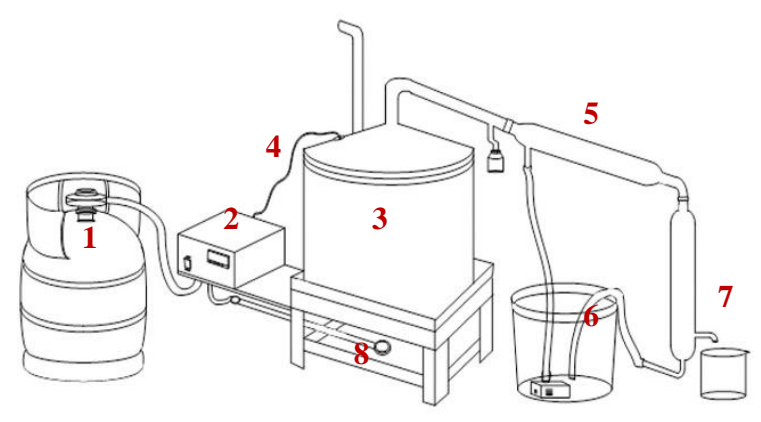

Gambar 1. Alat pirolisis

Keterangan gambar :

1. Tabung gas

2. Termokopel

3. Reaktor pirolisis

4. Kabel termokopel

5. Kondensor

6. Air Pendingin

7. Produk

8. Burner

\section{Bahan}

Batubara merupakan bahan utama pembuatan asap cair melalui pirolisis. Batubara yang digunakan bersumber dari Kecamatan Mallawa Kabupaten Bone Sulawesi Selatan yang disampling secara acak. Pembuatan pestisida menggunakan asap cair dan air $\left(\mathrm{H}_{2} \mathrm{O}\right)$ sebagai pelarut.

\section{B. Prosedur Penelitian}

Penelitian ini dilakukan dengan beberapa tahapan sebagai berikut:

1. Pembuatan asap cair

Sebelum dimasukkan ke dalam reaktor pirolisis, batubara dibersihkan terlebih dahulu dari pengotornya. Batubara yang telah bersih kemudian dihancurkan untuk memperoleh ukuran yang lebih kecil dengan menggunakan crusher.

Setelah itu bahan baku sebanyak $2 \mathrm{~kg}$ dimasukkan kedalam reaktor pirolisis, suhu diatur pada temperatur $300{ }^{\circ} \mathrm{C}$ dengan tekanan 1 atm. Jika suhu telah tercapai, proses pirolisis tetap berlangsung hingga 60 menit (holding time). Asap cair hasil pembakaran akan terkondensasi dan kemudian ditampung dalam sebuah wadah erlenmeyer. Asap cair ini dikategorikan sebagai asap cair grade 3.

2. Pembuatan variasi konsentrasi pestisida

Untuk membuat variasi konsentrasi pestisida dari asap cair dilakukan dengan melarutkan asap cair ke dalam air dengan volume sebagaimana yang ditunjukkan pada tabel 1 .

Tabel 1. Konsentrasi pestisida dari asap cair batubara

\begin{tabular}{|c|c|}
\hline Asap cair batubara (\%) & Air (\%) \\
\hline 100 & 0 \\
\hline 80 & 20 \\
\hline 60 & 40 \\
\hline 40 & 60 \\
\hline 20 & 80 \\
\hline
\end{tabular}

\section{Pengaplikasian asap cair pada rayap}

Pengujian pestisida organik dari asap cair batubara dilakukan dengan menyemprot rayap menggunakan asap cair yang telah dibuat dengan konsentrasi yang sesuai dengan tabel 1 diatas. Rayap yang digunakan berjumlah 15 ekor dalam kondisi sehat agar memudahkan proses pengamatan. Jumlah semprotan seragam untuk semua konsentrasi yaitu 3 semprotan dengan menggunakan botol spray $20 \mathrm{~mL}$.

\section{Hasil Penelitian}

\section{A. Pengaruh waktu terhadap mortalitas rayap}

Gambar 2 memperlihatkan asap cair hasil pirolisis batubara yang telah diencerkan menggunakan air $\left(\mathrm{H}_{2} \mathrm{O}\right)$. Asap cair memiliki karakteristik warna kekuningan dan memilliki bau khas asap. 


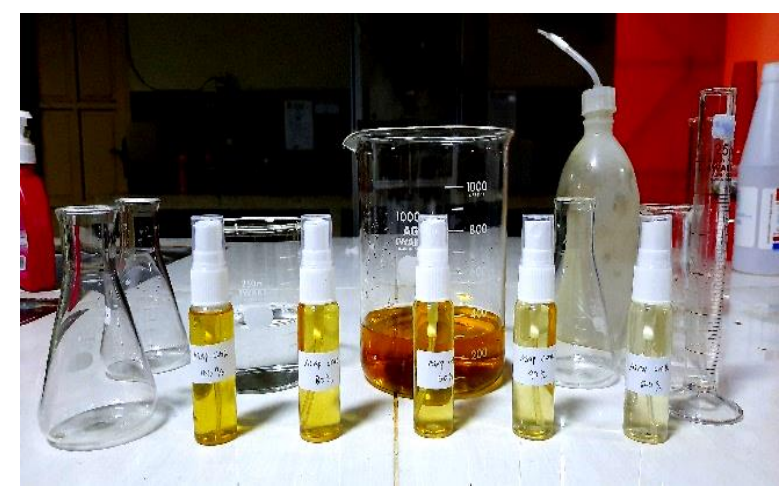

Gambar 2. Produk Asap Cair

Berdasarkan hasil penelitian dan pengamatan yang ditunjukkan pada gambar 2 diperoleh grafik hubungan konsentrasi asap cair batubara terhadap mortalitas rayap.

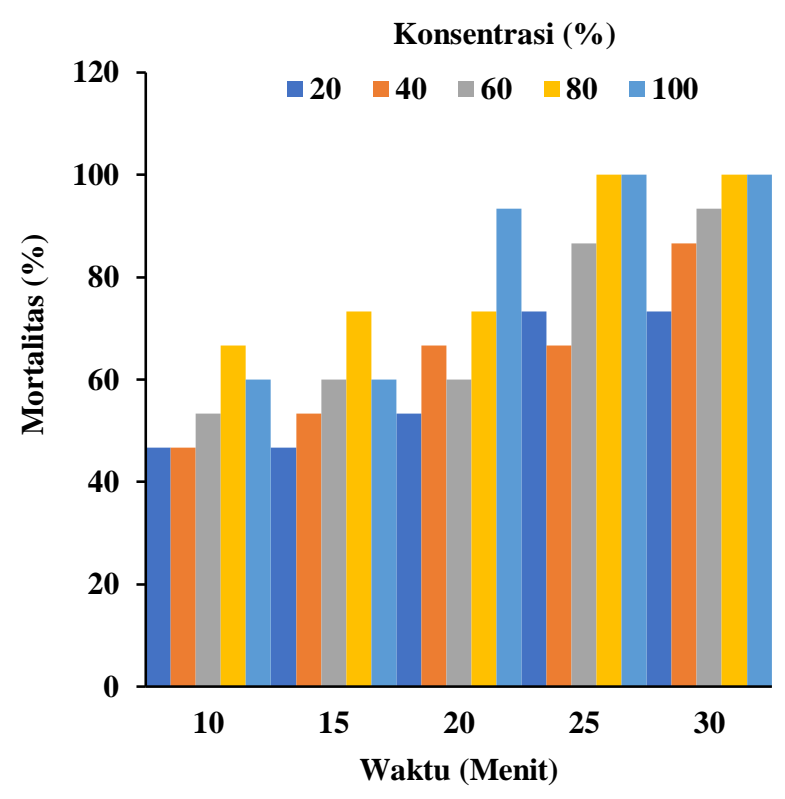

Gambar 3. Hubungan waktu terhadap mortalitas

Pada gambar 3 terlihat jika waktu optimum terhadap mortalitas rayap yaitu 25 menit dengan tingkat mortalitas $100 \%$. Penentuan tingkat mortalitas rayap ditentukan dengan melihat jumlah kematian rayap persatuan waktu. Tingkat kematian rayap terus meningkat berbanding lurus dengan waktu dan konsentrasi asap cair. Pada proses pengaplikasian asap cair, rayap yang dipakai masih sehat dan aktif. Seiring dengan berjalannya waktu rayap terlihat lemas dan pergerakannya melambat kemudian mati. Kematian rayap ini diduga akibat kandungan sulfur dan $\mathrm{pH}$ yang cukup rendah pada asap cair. Menurut balitbang pertanian, pestisida dikategorikan efektif jika menyebabkan mortalitas serangga uji lebih dari $80 \%$. Sulfur dapat memberikan efek dehidrasi pada serangga [13].

Sulfur telah digunakan sebagai pestisida sejak 1 abad sebelum Masehi. Penggunaan sulfur mulai menurun seiring dengan ditemukannya pestisida sintetis. Pestisida alami sulfur telah diuji efektifitasnya terhadap mortalitas Polyphagotarsonemus latus dengan dosis tunggal $0,5 \%$ sulfur mampu menimbulkan kematian 79,47\% [13].

\section{B. Pengaruh konsentrasi asap cair batubara terhadap mortalitas rayap}

Berdasarkan hasil penelitian dan pengamatan diperoleh Grafik pengaruh konsentrasi asap cair batubara terhadap mortalitas rayap sebagai berikut:

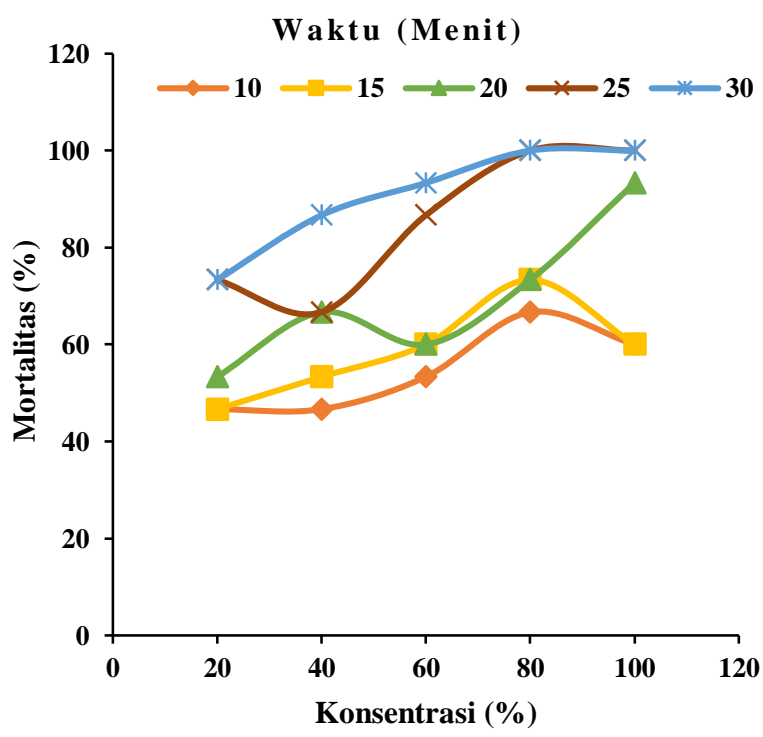

Gambar 4. Hubungan konsentrasi asap cair batubara terhadap mortalitas rayap

Pada gambar 4 terlihat jika konsentrasi optimum pada asap cair batubara sebagai pestisida terhadap mortalitas rayap yaitu pada konsentrasi $80 \%$ yaitu perbandingan antara asap cair dengan pengenceran $\mathrm{H}_{2} \mathrm{O}$ 80:20. Hasil pengamatan terlihat jika semua rayap yang digunakan sebagai sampel mati saat pengaplikasian asap cair, sehingga tingkat mortalitas rayap sebesar dianggap 100\%. Dari grafik juga terlihat jika konsentrasi asap cair 60:40 kematian rayap pada rentang waktu 25 dan 30 menit tingkat mortalitasnya diatas $80 \%$.

Berdasarkan hasil analisa spektrofotometer UV-VIS diperoleh kadar sulfur dari asap cair batubara sebesar 46,92 mg/kg dan derajat keasaman (pH) 3,00. Spektrofotometri UV-VIS bekerja berdasarkan pengukuran serapan cahaya di daerah ultraviolet (200 $-350 \mathrm{~nm})$ dan sinar tampak $(350-800 \mathrm{~nm})$ oleh suatu senyawa. Larutan sampel asap cair diukur serapan sinar ultra violet atau sinar tampaknya. Konsentrasi larutan asap cair yang dianalisis akan sebanding dengan jumlah sinar yang diserap oleh zat yang terdapat dalam larutan tersebut. Penentuan derajat 
keasaman $(\mathrm{pH})$ menggunakan alat $\mathrm{pH}$ meter. Berdasarkan hasil penelitian dari Subiyakto, dkk [4], menunjukkan bahwa pestisida alami kalsium polisulfida (sulfur) 1,25 mL/L air efektivitasnya tidak berbeda nyata dengan insektisida pembanding yang sudah dikomersialkan (Rotraz 200EC). Tingkat keasaman yang cukup tinggi memungkinkan pestisida dari asap cair batubara bisa dimanfaatkan secara luas dalam bidang pertanian.

\section{Kesimpulan}

Setelah melakukan penelitian pemanfaatan asap cair hasil pirolisis batubara sebagai pestisida organik pada rayap (Coptotermes curvignathus Holmgren) dapat disimpulkan:

1. Asap cair batubara sebagai bahan pestisida pada rayap (Coptotermes curvignathus Holmgren) dapat digunakan. Berdasarkan hasil pengamatan diperoleh waktu optimum terhadap mortalitas rayap yaitu 25 menit dengan tingkat mortalitas $100 \%$.

2. Kandungan sulfur yang cukup tinggi pada batubara yaitu $46,92 \mathrm{mg} / \mathrm{kg}$ dengan derajat keasaman $(\mathrm{pH})$ 3,00 dapat dimanfaatkan sebagai pestisida. Hasil penelitian diperoleh konsentrasi optimum dari pestisida asap cair dari bahan batubara yaitu konsentrasi $80 \%$ dengan tingkat mortalitas pada rayap sebesar $100 \%$.

3. Perlu adanya penelitian lanjutan untuk penggunaan asap cair dari hasil pirolisis sebagai pestisida pada beberapa varian serangga, hal ini dimaksudkan agar diperoleh perbandingan yang lebih banyak tentang efektifitas dari asap cair dari bahan batubara dengan kandungan sulfur yang cukup tinggi.

\section{Daftar Pustaka}

[1] M. Arman, A. Makhsud, A. Aladin, M. Mustafiah, and R. Abdul Majid, "Produksi bahan bakar alternatif briket dari hasil pirolisis batubara dan limbah biomassa tongkol jagung," J. Chem. Process Eng., vol. 2, no. 2, p. 16, 2017.

[2] I. Ishak, M. Wenny, and W. R. Sity, "Pemanfaatan asap cair tempurung kelapa sebagai pestisida organik terhadap mortalitas ulat grayak (Spodoptera Litura F.)," Jamb. J. Chem, vol. 1, no. 1, pp. 15-20, 2019.

[3] F. Kasim, A. N. Fitrah, and E. Hambali, “Aplikasi asap cair pada lateks," J. PASTI, vol. IX, no. 1, pp. 28-34, 2015.

[4] Subiyakto, N. Asbani, D. A. Sunarto, and Sujak, "Efikasi pestisida alami kalsium polisulfida (Sulfur) terhadap tungau (Polyphagotarsoneum latus L.)," Agrovigor, vol. 9, no. 1, pp. 42-47, 2016.

[5] M. Mustafiah, "Pemanfaatan Asap cair dari blending limbah biomassa cangkang sawit dan tempurung kelapa dalam secara pirolisis menjadi insektisida organik," J. Chem.
Process Eng., vol. 2, no. 1, p. 36, 2017.

[6] Anonim, Laporan Akhir: Kajian Ketercapaian Target DMO Batubara Sebesar 60\% Produksi Nasional pada Tahun 2019, BAPPENAS, Jakarta, 2016, p. 1-115.

[7] T. Dickerson and J. Soria, "Catalytic fast pyrolysis: A review," Energies, vol. 6, no. 1, pp. 514-538, 2013.

[8] E. Sari et al., "Production of liquid smoke from the process of carbonization of durian skin biomass, coconut shell and palm shell for preservation of Tilapia fish," IOP Conf. Ser. Mater. Sci. Eng., vol. 543, no. 1, 2019.

[9] F. Swastawati, E. Susanto, B. Cahyono, and W. A. Trilaksono, "Quality characteristic and lysine available of smoked fish," APCBEE Procedia, vol. 2, no. 2007, pp. 1-6, 2012.

[10] E. A. Nego, Abdul Hapid, Muthmainnah, and Erniwati, "Jenis rayap yang menyerang rumah penduduk di Kecamatan Sidoan Kabupaten Parigi Moutong Sulawesi Tegah," Jurnal Warta Rimba, vol. 8, no. 3, pp. 262-267, 2020.

[11] I. A. Impact and N. Subekti, "Karakteristik populasi rayap tanah Coptotermes spp (Blattodea: Rhinotermitidae) dan dampak serangannya," Biosaintifika J. Biol. Biol. Educ., vol. 2, no. 2, pp. 110-114, 2010.

[12] R. S. Santoso, “Asap cair sabut kelapa sebagai repelan bagi hama padi Walang Sangit ( Leptocorisa oratorius )," J. Sainsmat, vol. IV, no. 2, pp. 81-86, 2015.

[13] Anonim, "Pestisida alami sulfur ampuh mengendalikan hama tungau," Warta Penelitian dan Pengembangan Pertanian, vol. 4, pp. 12-14, 2011. 